\title{
VERIFIKASI ANALISA KADAR LOGAM TIMBAL (Pb) DALAM DARAH DAN GAMBARAN HEMATOLOGI DARAH PADA PETUGAS TAMBANG BATU BARA
}

\author{
Betti Rosita $^{(1)}$, Eri Sosmira ${ }^{(2)}$ \\ Sekolah Tinggi Ilmu Kesehatan Perintis Padang \\ Jalan Adinegoro KM 17 Simpang Kalumpang Padang \\ Email: bettirosita@yahoo.co.id
}

\begin{abstract}
Verification is performed on a method to prove that the relevant laboratory is capable of testing by such method with valid results Validation of the results of the examination to be performed by laboratory personnel to reinforce and confirm that the method used in accordance with its use, such as in the use of wet digestion method with test equipment that supports the laboratory is an Atomic Absorption Spectrometer (AAS), principally for the analysis of metal content in blood samples. One of the metals that may be contaminated with blood are metal Plumbum $(\mathrm{Pb})$ threats to health such as the circulatory system and the central nervous system of humans, other negative impacts caused that damage to the kidneys, anemia, liver and reproductive system of humans. This research is an experiment, The results showed the blood sample examination officer Bara stone mine average $\mathrm{Pb}$ content results are still below the threshold (NAB) is $0.292 \mathrm{mg} / \mathrm{L}$ in accordance with Kepmenkes No. 14062002 of $<10 \mathrm{~g} / \mathrm{L}$ of blood price $0.5996 \%$ precision (<2\%), the accuracy of 104.55\% (100\% $\pm 15 \%)$, LOD and LOQ 0.02529820 .007589946 ppm ppm for the validation of the results can be stated that the method of destruction wet for test equipment SSA fit for use and picture examination results of laboratory hematolgi blood samples showed the complete blood still in the normal range wher eas when viewed in counts an increase in lymphocytes of $40 \%$ and 37\% (normal 25-35\%) and monocyte $6 \%$ (normally $2-4 \%$ ) indicate that the blood of those officers already contain lead $(\mathrm{Pb}$ ).
\end{abstract}

Key words : Verification, Plumbum, blood, SSA, destruction Wet

\section{PENDAHULUAN}

Sampel yang dianalisa pada berbagai laboratorium, kenyataan yang seringkali ditemukan yaitu hasil yang berbeda-beda. Pengambilan keputusan yang salah dari perbedaan hasil analisis tersebut dapat berakibat fatal misalnya bagi kesehatan manusia. Oleh karena itu, dapat dibayangkan betapa besar biaya yang harus dikeluarkan apabila hasil uji dinyatakan tidak akurat sehingga produk ditolak/dilakukan analisis ulang.

Pada kenyataannya memang berbagai faktor dapat mempengaruhi mutu hasil analisis, tetapi secara umum hasil analisis yang benar dan absah akan diperoleh apabila metode dan instrument yang digunakan telah terverifikasi. Verifikasi adalah konfirmasi, melalui penyediaan bukti objektif, bahwa persyaratan yang telah ditentukan telah dipenuhi (ISO/IEC 17025: 2005). Validasi hasil pemeriksaan perlu dilakukan oleh petugas Laboratorium untuk mempertegas dan mengkonfirmasi bahwa metode yang digunakan sesuai dengan penggunaannya, seperti dalam penggunaan metoda destruksi basah dengan alat uji yang mendukung laboratorium adalah Spektrometer Serapan Atom (SSA) (Rahayu, 2012) , prinsipnya untuk analisa kandungan logam dalam sampel darah. Salah satu logam yang 
dapat tercemar dalam darah adalah logam Plumbum $(\mathrm{Pb})$ ancamannya terhadap kesehatan seperti pada sistem peredaran darah serta sistem syaraf pusat manusia, dampak negatif lain yang ditimbulkan yaitu kerusakan pada ginjal, anemia, liver dan sistem reproduksi manusia. Salah satu sumber pencemaran $\mathrm{Pb}$ adalah dari limbah pencucian batu bara

Nilai Ambang Batas Pb pada tubuh manusia Menurut Menteri Kesehatan (2002) dalam Keputusan Menteri Kesehatan Republik Indonesia Nomor 1406/MENKES/SK/IX/2002 tentang standar pemeriksaan kadar timah hitam pada specimen biomarker manusia, pengukuran kadar timbal pada tubuh manusia dapat dilakukan melalui specimen darah, urin, dan rambut. Spesimen darah Nilai ambang batas kadar timbal dalam specimen darah pada orang dewasa normal adalah 10-25 $\mu \mathrm{g} / \mathrm{dl}$. Untuk menentukan Komponen Darah secara Diferential Count (Hitung Jenis Leukosit) ( Priyanto,2010), dengan melakukan hitung jenis leukosit, pertama membuat sediaan apus darah yang diwarnai dengan pewarna Giemsa, Wright atau May grunwald. Amati di bawah mikroskop dan hitung jenis-jenis leukosit hingga didapatkan 100 sel. Tiap jenis sel darah putih dinyatakan dengan persen (\%). Jumlah absolut dihitung dengan mengalikan persentase jumlah dengan hitung leukosit, hasilnya dinyatakan dalam sel $/ \mu \mathrm{L}$. Hitung jenis leukosit digunakan untuk mengetahui jumlah berbagai jenis leukosit. Terdapat lima jenis leukosit, yang masing-masingnya memiliki fungsi yang khusus dalam melawan pathogen. Sel-sel itu adalah neutrofil, limfosit, monosit, eosinophil dan basophil. Hasil itu jenis leukosit memberikan informasi yang lebih spesifik mengenai infeksi dan proses penyakit.

\section{Verifikasi dan Validasi}

Verifikasi adalah konfirmasi, melalui penyediaan bukti okjektif, bahwa persyaratan yang telah ditentukan telah dipenuhi (ISO/IEC 17025 : 2005). Dalam verifikasi metode, kinerja yang di uji adalah keselektifan, seperti uji akurasi (ketetapan) dan presisi (kecermatan). Suatu metode yang presisi (cermat) belum menjamin bahwa metode tersebut dikatakan dapat (akurat). Begitu juga sebaliknya, suatu metode yang tepat (akurat) belum tentu presisi.

Validasi metode analisis metode adalah proses dimana suatu metode ditetapkan melalui serangkaian uji laboratorium untuk mengetahui bahwa parameter metode yang di uji memenuhi persyaratan untuk penerapan metode yang dimaksud. Tujuan utama validasi adalah untuk menjamin metode analisis yang digunakan mampu memberikan hasil yang cermat, handal, dan dapat dipercaya. Dalam ISO/IEC 17025:2005, parameter metode analisis adalah kecermatan (akurasi), repitabilitas (presisi), selektivitas, linialitas, rentang, batas kuantitasi (LOQ) dan batas deteksi (LOD), ketangguhan, dan kekuatan (Wegscheider,1996)

\section{Akurasi}

Akurasi atau kecermatan adalah ukuran yang menunjukkan derajat kedekatan hasil analisis dengan kadar analit yang sebenarnya. Biasanya dinyatakan sebagai persen perolehan kembali. Cara untuk menentukan kecermatan dalam ISO/IEC 17025: 2005 adalah dengan pengujian menggunakan CRM (Certified Reference Material) setidak-tidaknya dilakukan 7 kali pengulangan analisis tiap CRM. Kriteria akurat diberikan jika hasil analisis memberikan nilai antara 98\%-102\%. Untuk sampel biologis dan nabati, syarat akurasi yang baik adalah $\pm 10 \%$ dari syarat akurasi untuk sediaan (98\%102\%) (Sumardi,2002)

\section{Presisi}

Repitabilitas atau presisi adalah yang menunjukkan derajat kesesuaian antara hasil uji individual yang diukur melalui penyebaran hasil individu dari hasil rata-rata jika prosedur ditetapkan secara berulang pada sampel-sampel yang diambil dari campuran yang homogenkan. Cara untuk menentukan repitabilitas dalam ISO/IEC 17025: 2005 adalah dengan pengujian sampel setidak-tidaknya dilakukan 7 kali pengulangan tiap sampel (Sumardi,2002).

\section{Selektivitas}

Yang dimaksud selektivitas adalah kemampuan dari metode tersebut untuk mengukur analit tertentu saja secara cermat dan seksama dengan adanya komponen lain yang mungkin ada di dalam matriks sampel. Selektivitas sering kali dinyatakan sebagai 
derajat penyimpangan metode yang dilakukan terhadap sampel dengan penambahan cemaran, hasil urai, senyawa sejenis, atau senyawa asing lainnya. Hasil dari sampel tersebut dibandingkan dengan hasil analisis sampel yang tidak mengandung bahan lain yang ditambahkan (Sumardi,2002).

\section{Linearitas}

lineritas adalah kemampuan metode analisis untuk memberikan respon secara langsung atau dengan bantuan transformasi matematika yang baik dan proposional terhadap konsentrasi analit dalam sampel. Linearitas dapat diperoleh dengan konsentrasi standar yang berbeda, minimal lima konsentrasi. Data yang diperoleh nili slope, intersep, dan koefisien korelasi. Nilai koefisien korelasi diatas 0,9990 sangat diharapkan suatu metode analisis yang baik. Selain koefisien korelasi, simpang baku residual (Sy) juga harus dihitung. Semua perhitungan matematika tersebut dapat diukur menggunakan kalkulator atau perangkat lunak computer.

\section{Rentang (Range)}

Rentang metode adalah pernyataan batas terendah dan analit yang telah ditunjukkan dan dapat ditetapkan kecermatan, keseksamaan dan linieritas yang dapat diterima

\section{Batas kuantitasi (LOQ) dan Batas Deteksi (LOD)}

Batas kuantitasi merupakan parameter pada analisi renik dan diartikan jumlah terkecil analit dalam sampel yang dapat memenuhi kriteria cermat dan seksama. Batas deteksi adalah jumlh analit terkecil dalam sampel

\section{Spektrofotometer Serapan Atom (SSA)}

Spektrofotometer Serapan Atom (SSA) adalah suatu alat yang digunakan pada metode analisis untuk penentuan unsur-unsur logam dan metaloid yang berdasarkan pada penyerapan absorbsi radiasi oleh atom bebas. Spektrofotometer Serapan Atom adalah spektroskopi berdasarkan atom yang pertama kali di andalkan untuk menganalisa kandungan logam yang terdapat pada sampel dari lingkungan (Asrul, 2004)

\section{Destruksi basah}

Destruksi basah yaitu pemanasan sampel (organic atau biologis) dengan adanya pengoksidasi kuat seperti asam-asam mineral baik tunggal maupun campuran. Jika dalam sampel dimasukkan zat pengoksidasi, lalu dipanaskan pada temperature yang cukup tinggi dan jika pemanasan dilakukan secara kontinu pada waktu yang cukup lama, maka sampel yang teroksidasi sempurna sehingga meninggalkan berbagai elemen-elemen pada larutan asam dalam bentuk senyawa anorganik yang sesuai untuk dianalisis.

Destruksi basah pada prinsipnya adalah penggunaan asam nitrat untuk mendestruksi zat organic pada suhu rendah dengan maksud mengurangi kehilangan mineral akibat penguapan. Pada tahap selanjutnya, proses seringkali berlangsung sangat cepat akibat pengaruh asam perklorat atau hidrat proksida.

\section{METODE PENELITIAN}

Penelitian ini bersifat eksperimen dan metoda yang digunakan untuk penentuan kadar $\mathrm{Pb}$ dalam darah yaitu dengan destruksi basah dan selanjutnya logam dianalisis dengan SSA, pemeriksaan dilanjutkan dengan pengujian sampel darah yang mengandung $\mathrm{Pb}$ di laboratorium hematologi, untuk menentukan nilai yang terdapat dalam komponen darah. Tujuan penelitian ini adalah untuk mengetahui Validasi Hasil Pemeriksaan Kadar Logam Timbal $(\mathrm{Pb})$ Dalam Darah Dan Gambaran Hematologi Darah Pada Petugas Tambang Batu Bara . Alat yang digunakan pada saat penelitian adalah: SSA, labu ukur, labu destruksi, pipet takar, Pipet tetes, corong, kertas saring, botol sampel, vial, kertas label, beaker glass. Bahan yang digunakan pada saat penelitian adalah: sampel darah vena, larutan HNO3 pekat, tisu, aguadest bebas $\mathrm{Pb}$ (aquabidest), larutan standar $\mathrm{Pb}(0,2$; $0,4 ; 0.6 ; 0.8 ; 1)$ ppm, kapas kering dan kapas alkohol $70 \%$

\section{Pengambilan darah vena}

Pasang tali pembendung (tourniquet) kira - kira $10 \mathrm{~cm}$ di atas lipat siku, lakukan perabaan untuk memastikan posisi vena. Jika vena tidak teraba, lakukan pengurutan dari arah pergelangan ke siku, atau kompres hangat selama 5 menit daerah lengan. Bersihkan kulit pada bagian yang akan diambil dengan kapas 
alkohol $70 \%$ san biarkan kering. Kulit yang sudah dibersihkan jangan dipegang lagi. Tusuk bagian vena dengan posisi lubang jarum menghadap ke atas ( 30 ). Apabila darah sudah terlihar pada indikator, pasang tabung vakum dan tunggu darah sampai penuh. Saat darah masuk kedalam tabung vakum, tali pembendung (tourniquet) dilepaskan. Setelah terisi penuh, beri label pada tabung dan tangan pasien diberi plaster.Sampel dapat disimpan dengan suhu $18 \mathrm{C}$ sampai $20 \mathrm{C}$

\section{Pembuatan larutan standar}

1. Pembuatan Larutan Induk 1000 ppm

2. Pembuatan Larutan Baku $\mathrm{Pb} 100$ ppm

3. Pembuatan Deret Standar 0,2;0,4;0.6;0,8; 1

\section{Pemeriksaan Sampel}

Pipet $50 \mathrm{ml}$ sampel whole blood dan masukkan kedalam labu destruksi yangberalaskan beaker glass. Ditambahkan $5 \mathrm{ml}$ aguadest dan tambahkan $10 \mathrm{ml} \mathrm{HNO} 3$ pekat. Destruksi hingga jernih dan tepatnya mencapai volume $5 \mathrm{ml}$. Dinginkan, masukkan kedalam botol, beri label dan ukur dengan SSA.

Pengukuran Larutan Standar dengan Alat SSA

Penentuan panjang gelombang maksimum dilakukan terlebih dahulu dengan memasang lampu kode berongga $\mathrm{Pb}$ lalu dihidupkan tombol power pada alat SSA, kemudian diatur lampu sesuai dengn logam yang diinginkan melalui sofware. Diatur panjang gelombang menurut instruksi manual $\mathrm{SSA}$, logam $\mathrm{Pb}$ dengan panjang gelombang $283 \mathrm{~nm}$. Panjang gelombang yang diperoleh pada kurva absorbsi maksimum ini digunakan untuk pengukuran konsentrasi logam $\mathrm{Pb}$ dalam sampel.

Uji akurasi (ketepatan)

Uji ini dilakukan dengan cara menambahkan larutan baku pembanding kedalam sampel yang akan diperiksa Kemudian dilakukan uji blanko (tanpa penambahan larutan baku standar)Hasil perolehan kembali dinyatakan dengan persen.Tes darah akan menyebar disisi kaca penggeser. Tunggu sampai darah mencapai titik kira-kira $1 / 2 \mathrm{~cm}$ dari sudut kca penggeser.Segeralah geserkan kaca itu ke kiri sambil memegangnya miring dengan sudut diantara $30-45^{\circ}$. Biarkan sediaan itu kering di udara. Tulislah nama pasien dan tanggal pembuatan pada bagian sediaan yang tebal.

Uji presisi(sensitivitas)

Uji sensitivitas dilakukan dengan mengukur satu macam konsentrasi logam $\mathrm{Pb}$ adalah $1,0 \quad \mathrm{mg} / \mathrm{l}$ dengan $6 \quad$ kali ulangan.Kemudian data hasil absorb dihitung simpangan baku, rata-rata dan simpang baku relative (RSD)

\section{Uji limit deteksi (LOD)}

Uji ini dilakukan dengan mengukur konsentrasi standar yang paling rendah yang dapat terdeteksi absorbnya.Kemudian yang dapat terdeteksi rendah itu diulang selama 5 kali.

\section{HASIL DAN PEMBAHASAN}

\section{Dekstruksi Sampel Darah}

Hasil analisa kandungan plumbum $(\mathrm{Pb})$ dalam darah karyawan Batu Bara dapat dilihat pada Tabel 4.1 didapatkan kadar $\mathrm{Pb}$ dalam darah Menunjukkan bahwa semua sampel yang diperiksa masih di bawah Nilai Ambang Batas (NAB) karena sesuai dengan Kepmenkes No. 1406/Menkes/SK/XI/2002 tentang Standar Pemeriksaan Kadar $\mathrm{Pb}$ pada spesimen Biomarker manusia bahwa kandungan Timbal (Pb) $0.1-0.25 \mu \mathrm{g} / \mathrm{ml}$

Tabel 1 Kadar $\mathrm{Pb}$ dalam sampel darah

\begin{tabular}{ccccc}
\hline No & $\begin{array}{c}\text { Jenis } \\
\text { Sampel }\end{array}$ & $\begin{array}{c}\text { Masa } \\
\text { Kerja }\end{array}$ & $\begin{array}{c}\text { Rata-rata Lama } \\
\text { kerja/ hari }\end{array}$ & $\begin{array}{c}\text { Konsentrasi Pb dalam } \\
\text { Darah }(\mathrm{mg} / \mathrm{L})\end{array}$ \\
\hline 1 & Sampel I & 5 Tahun & 8 Jam & $0,272 \mathrm{mg} / \mathrm{L}$ \\
2 & Sampel II & 7 Tahun & 8 Jam & $0,312 \mathrm{mg} / \mathrm{L}$ \\
\hline
\end{tabular}

Journal of Sainstek. ISSN: 2085-8019 (p), 2580-278X (e).

Published by Association of Mathematics Science Education and Technology

State Institute for Islamic Studies (AMSET-IAIN) Batusangkar 


\section{Uji Akurasi}

Hasil uji akurasi untuk metode dekstruksi basah dengan menggunakan $\mathrm{HNO}_{3}$ mempunyai rata-rata recovery $104.55 \%$ dengan demikian metode dekstruksi ini sudah baik berada pada nilai kisaran persentase resevory yang disarankan, yaitu pada rentang $100 \% \pm 15$ dengan nilai yang lebih mendekati $100 \%$. Data dapat dilihat pada table 4.2

Tabel 2. Nilai Persentase Recovery Analisa Plumbum (Pb) dalam Darah pada Petugas Tambang Batu Bara

\begin{tabular}{cccccc}
\hline Sampel & $\begin{array}{c}\text { Volume } \\
\text { Sampel }\end{array}$ & $\begin{array}{c}\text { Spake } \\
\mathrm{Pb} \mu \mathrm{g}\end{array}$ & $\begin{array}{c}\text { Jumlah } \mathrm{Pb} \\
\text { Teoritis } \mu \mathrm{g}\end{array}$ & $\begin{array}{c}\text { Jumlah } \mathrm{Pb} \\
\text { Analisis } \mu \mathrm{g}\end{array}$ & Recovery \\
\hline $\mathrm{A}$ & $10 \mathrm{ml}$ & & & 0.156 & \\
$\mathrm{~A}+10 \mathrm{ml} \mathrm{pb}$ & $10 \mathrm{ml}$ & 4.8 & 6.36 & 0.643 & 101.10 \\
$\begin{array}{c}0.48 \mathrm{ppm} \\
\mathrm{A}+10 \mathrm{ml} \mathrm{pb}\end{array}$ & $10 \mathrm{ml}$ & 6.0 & 7.56 & 0.794 & 105.03 \\
$\begin{array}{c}0.60 \mathrm{ppm} \\
\mathrm{A}+10 \mathrm{ml} \mathrm{pb}\end{array}$ & & & & & \\
$0.72 \mathrm{ppm}$ & $10 \mathrm{ml}$ & 7.2 & 8.76 & 0.942 & 107.53 \\
& & & & Rata-rata & $104.55 \%$ \\
\hline
\end{tabular}

\section{Uji Presisi}

Kadar $\mathrm{Pb}$ dalam darah merupakan salah satu indikator terakumulasinya logam $\mathrm{Pb}$ dalam tubuh.Syarat analisa logam dengan menggunakan SSA adalah sampel harus berupa larutan, maka sebelum kadar $\mathrm{Pb}$ dianalisis dilakukan dekstruksi terlebih dahulu. Fungsi dari dekstruksi adalah untuk memutus ikatan antara senyawa organik dengan logam yang akan dianalisis. Dalam penelitian ini digunakan dekstruksi basah menggunakan $\mathrm{HNO}_{3}$ karena pada umumnya dekstruksi basah dapat dipakai untuk untuk menentukan unsur-unsur dengan konsentrasi rendah.setelah proses dekstruksi diharapkan yang tertinggal hanya logam-logam saja dalam bentuk ion. Pelarut yang digunakan untuk dekstruksi basah adalah asam nitrat.. Sampel darah yang digunakan dalam penelitian ini diperoleh dari petugas batu bara. Logam yang dianalisa yaitu $\mathrm{Pb}$ diukur dengan SSA dengan panjang gelombang 283,3 $\mathrm{nm}$. Melalui pemeriksaan Laboratorium, analisa sampel dilakukan dengan cara membandingkan standar yang ada yaitu menurut Kepmenkes RI No.1406 tahun 2002 tentang Standar Pemeriksaan Kadar Pb Spesimen Biomarker
Manusia artinya melihat di atas atau di bawah NAB. Hasil analisa didapatkan bahwa kedua sampel $<10 \mu \mathrm{g} / \mathrm{L} \mathrm{Pb}$. Dimana koefisien variasi 25 atau kurang. Kandungan Timbal $(\mathrm{Pb})$ dalam darah sampel masih dibawah ambang batas dikarenakan para petugas Batu bara berumur di bawah dari 30 tahun sehingga memungkinkan rendahnya kandungan $\mathrm{Pb}$. Waktu paruh $\mathrm{Pb}$ secara biologi dalam tubuh manusia diperkirakan 2-3 tahun. Timbal dalam darah akan dapat dideteksi dalam waktu paruh sekitar 20 hari, sedangkan ekskresi $\mathrm{Pb}$ dalam tubuh secara keseluruhan terjadi dalam waktu paruh sekitar 28 hari. Dari darah dan tempat deposit, $\mathrm{Pb}$ kemudian diekskresikan melalui urine, feces dan keringat (Riyadina, 1997 dalam Naria, 2005). Umur dan jenis kelamin juga mempengaruhi kandungan $\mathrm{Pb}$ dalam jaringan tubuh. Semakin tua umur seseorang akan semakin tinggi pula konsentrasi $\mathrm{Pb}$ yang terakumulasi pada jaringan tubuhnya. Jenis jaringan juga turut mempengaruhi kadar $\mathrm{Pb}$ yang dikandung tubuh (Palar, 1994 dalam Kurniawan, 2008). Data uji presisi dapat dilihat pada table 4.3 
Tabel 3. Hasil Uji Presisi

\begin{tabular}{llll}
\hline No & Konsentrasi Larutan $(\mathrm{x})$ & $\mathrm{X}-\mathrm{X}$ & $(\mathrm{X}-\mathrm{X})^{2}$ \\
\hline 1 & 0.597 & -0.002 & 0.000004 \\
2 & 0.601 & 0.002 & 0.000004 \\
3 & 0.599 & 0 & 0 \\
4 & 0.597 & -0.002 & 0.000004 \\
5 & 0.601 & 0.002 & 0.000004 \\
6 & 0.603 & 0.004 & 0.000016 \\
& $\sum \mathrm{X}=3.598 / 6$ & & \\
& $\mathrm{X}=0,5996$ & & \\
\hline
\end{tabular}

\section{Uji Lineiritas}

Uji linieritas suatu metode bertujuan membuktikan adanya hubungan yang linier antara konsentrasi analit yang sebenarnya dengan respon alat. Parameter yang menunjukkan adanya hubungan yang linier antara absorbansi dengan konsentrasi analit adalah koefisien (r). untuk itu, dilakukan uji linieritas melalui pembuatan kurva kalibrasi standard an pengukuran absorbansi deret larutan dengan SSA.

Berdasarkan pengukuran sederet larutan standar, diperoleh nilai korelasi (r) sebesar 0,9996. Pada gambar dapat dilihat bawah kurva kalibrasi standar tersebut mempunyaigaris singgung yang linear respon yang diberikan alat terhadap konsentrasi analit telah memenuhi syarat., nilai $\mathrm{r}=0,9996$ yang diperoleh telah memenuhi syarat yang ditetapkan, dengan ketentuan $r>0,99$.hasil tersebut menunjukkan alat yang digunakan mempunyai respon yang baik terhadap sampel.

Uji Limit of Detection (LOD) dan Limit of Quantitation (LOQ)

Parameter limit deteksi (LoD) instrument menunjukkan kosentrasi terkecil yang dapat terbaca oleh instrument. Pada kosentrasi terkecil yang berada pada limit deteksi alat sangat terbatas dalam membedakan antara sinyal analit dengan noise. Apabila kosentrasi berada di bawah limit detekni maka sinyal yang ditangkap alat adalah sepenuhnya nose. Konsentrasi analit yang berada pada limit deteksi belum sepenuhnya dapat dipercaya karena akurasi yang dihasilkan rendah.

Sementara itu, limit kauntitasi (LoQ) didefenisikan sebagai kosentrasi analit terendah dalam sampel yang dapat ditentukan dengan presisi dan akurasi yang dapat diterima pada kondisi operasional metode yang digunakan. LoQ merupakan suatu kompromi antara kosentrasi dengan presisi dan akurasi yang dipersyaratkan. Jika kosentrasi LoQ menurun maka presisi juga menurun. Jika presisi tinggi dipersyaratkan, maka kosentrasi LoQ lebih tinggi harus dilaporkan.

Hasil tersebut dapat dilihat pada gambar kurva kalibrasi larutan standar timbal ( $\mathrm{Pb}$ ) yang menunjukkan titik konsentrasi dari kedua metode. Dalam kurva kalibrasi menunjukkan hasil yang linear, namum pengukuran harus mencapai limit kuantitasi agar pengukuran lebih akurat. Dengan dmikian sesuai dengan gambar kurva kalibrsi larutan standar timbal, hasil pengukuran metode destruksi kedua dikatakan lebih baik dengan konsentrasi yang melebih LOQ sehingga memberikan hasil dengan akurasi yang tinggi.

Gambaran hasil pemeriksaan hematologi darah yang mengandung $\mathbf{P b}$

Darah merupakan komponen esensial makhluk hidup yang merupakan bagian terpenting dalam system transport. Dalam keadaan fisiologik, darah selalu ada dalam pembuluh darah sehingga dapat menjalankan fungsinya sebagai pembawa oksigen, mekanisme pertahanan tubuh terhadap infeksi 
dalam darah terdapat beberapa kompenenkompenen darah seperti Hemoglobin $(\mathrm{Hb})$ dimana nilai normalnya 12-16 wanita, $13-18$ laki-laki, $\mathrm{Hb}$ rendah biasa dikaitkan dengan anemia defisiensi besi, $\mathrm{Hb}$ tinggi berkaitan dengan luka bakar,dehidrasi/diare dll.

Tabel 4 Gambaran Hasil pemeriksaan hematologi darah yang mengandung $\mathrm{Pb}$

\begin{tabular}{|c|c|c|c|c|c|}
\hline No & Jenis Sampel & Masa Kerja & Parameter & Nilai normal & Hasil \\
\hline \multirow[t]{12}{*}{1} & Sampel I & 5 tahun & Hemoglobin & $12-18 \mathrm{gr} / \mathrm{dl}$ & 12,8 \\
\hline & & & Leukosit & $5-10 \mathrm{sel} / \mathrm{mm}^{3}$ & 6.000 \\
\hline & & & Eritrosit & $4-6$ juta & 4,4 \\
\hline & & & Hematokrit & $37-47 \%$ & 39 \\
\hline & & & Trombosit & $150.000-400.000 \mathrm{sel} / \mathrm{mm}^{3}$ & 425.000 \\
\hline & & & Diffcount & & \\
\hline & & & Basofil & $0-1 \%$ & 0 \\
\hline & & & Eosinofil & $1-3 \%$ & 1 \\
\hline & & & Net. Batang & $3-5 \%$ & 2 \\
\hline & & & Net. Segmen & $50-70 \%$ & 51 \\
\hline & & & Limfosit & $25-35 \%$ & 40 \\
\hline & & & Monosit & $2-4 \%$ & 6 \\
\hline \multirow[t]{12}{*}{2} & Sampel II & 7 tahun & Hemoglobin & $12-18 \mathrm{gr} / \mathrm{dl}$ & 15.7 \\
\hline & & & Leukosit & $5-10 \mathrm{sel} / \mathrm{mm}^{3}$ & 8.700 \\
\hline & & & Eritrosit & $4-6$ juta & 5,5 \\
\hline & & & Hematokrit & $37-47 \%$ & 46 \\
\hline & & & Trombosit & $150.000-400.000 \mathrm{sel} / \mathrm{mm}^{3}$ & 335.000 \\
\hline & & & Diffcount & & \\
\hline & & & Basofil & $0-1 \%$ & 0 \\
\hline & & & Eosinofil & $1-3 \%$ & 3 \\
\hline & & & Net. Batang & $3-5 \%$ & 2 \\
\hline & & & Net. Segmen & $50-70 \%$ & 52 \\
\hline & & & Limfosit & $25-35 \%$ & 37 \\
\hline & & & Monosit & $2-4 \%$ & 6 \\
\hline
\end{tabular}

Hematokrit nilai normal dewasa pria $40-$ $45 \%$, wanita $37-47 \%$, hematocrit merupakan persentase konsentrasi eritrosit dalam plasma darah. Ht tinggi dapat ditemukan pada berbagai kasusu seperti pada luka bakar, dehidrasi/ diabetes, sedangkan Ht rendah dapat ditemukan pada anemia. Leukosit nilai normal 5000-10000 $\mathrm{sel} / \mathrm{mm}^{3}$ segala macam infeksi menyebabkan leukosit naik,baik infeksi bakteri, virus, parasit dan sebagainya leukosit rendah disebabkan oleh anemia, keracunan kimiawi. Leukosit( hitung jenis) nilai normal hitung jenis

Basophil 0-1\%,Eosinofil 1-3\%,Netrofil batang 3-5\%,Negrofil segmen 50-70\%, Limfosit 25-35\%, Monosit $4-6 \%$
Peningkatanhitung jenis jarang memberi nilai diagnostic, kecuali untuk alergi dimana eosinophil sering ditemukan meningkat. Peningkatan jumlah netrofil(baik batang maupun segmen) relative disbanding limfosit dan monosit dikenal juga dengan sebutan shift to the left. Infeksi yang disertai shift to the left biasanya merupakan infeksi bakteri dan malaria. Kondisi noninfeksi yang dapat menyebabkan shift to the left luka bakar dan keracunan merkuri( raksa) sedangkan peningkatan jumlah limfosit dan monosit relatif dibandingkan netrofil disebut shift to the right biasanya merupakan infeksi virus. Kondisi noninfeksi yang dapat menyebabkan shift to the 
right antara lain keracunan timbal dll. Trombosit nilai normal $150.000-400.000$ $\mathrm{sel} / \mathrm{mm}^{3}$. Hitung eritrosit nilai normal dewasa wanita $4.0-5.5$ juta $\mathrm{sel} / \mathrm{mm}^{3}$, pria $4.5-6.2$ juta $\mathrm{sel} / \mathrm{mm}^{3}$. Hasil tersebut dapat dilihat pada pada tabel 4 .

\section{KESIMPULAN}

Dari penelitian yang telah dilakukan dapat disimpulkan:

1. Pada 2 sampel darah petugas batu bara, rata - rata kandungan $\mathrm{Pb}$ masih di bawah $\mathrm{NAB}$ yaitu $0.146 \mu \mathrm{g} / \mathrm{ml}$ sesuai dengan Kepmenkes No. 1406 tahun 2002 dimana nilai normal $\mathrm{Pb}$ dalam darah yaitu $0,1-0.25 \mu \mathrm{g} / \mathrm{ml}$. Berdasarkan hasil uji presisi $0.422 \%$, akurasi $104.55 \%$, LOD 0,00758946 ppm dan LOQ $0,0252982 \mathrm{ppm}$. Validasi metoda dekstruksi basah menggunkan $\mathrm{HNO}_{3}$ untuk analisis unsur $\mathrm{Pb}$ dengan kisaran konsentrasi tersebut di atas, masih memenuhi persyaratan dengan harga presisi $\leq 2 \%$, dan akurasi $100 \% \pm 15 \%$ yang teliti dapat disimpulkan bahwa metoda dekstruksi ini dapat dipercaya atau lebih valid untuk analisis $\mathrm{Pb}$ dalam darah dengan menggunakan SSA

2. Gambaran hasil pemeriksaan hematologi darah yang mengandung $\mathrm{Pb}$ dari petugas batu bara untuk gambaran sel darah dimana darah lengkap masih dalam rentang normal sedangkan bila dilihat dalam hitung jenis terjadi peningkatan pada limfosit $40 \%$ dan $37 \%$ dan monosit $6 \%$ dimana normal Limfosit $(25$ - $35 \%)$ sedangkan Monosit normalnya $(2-4 \%)$ menandakan bahwa darah petugas tersebut sudah mengandung timbal $(\mathrm{Pb})$. Semakin lama seseorang itu bekerja maka semakin tinggi kadar timbal dalam darahnya.

\section{DAFTAR KEPUSTAKAAN}

Asrul. 2004. Persiapan Peralatan ASS: Perawatan, Permasalahan dan Pemecahannya.Sarpedal Kementerian Lingkungan Hidup.

Harmita. 2004. Petunjuk Pelaksanaan Validasi Metode dan cara perhitungannya. Majalah Ilmu Kafarmasian.

Haryanto A. 2004. Analisis Pangan. Departemen Pendidikan dan Kebudayaan. Bogor.

Herdiantini E. 2003. Analisis Bahan tambahan Kimia. Fakultas Teknik Universitas Pasudan, Bandung.

Kepmenkes RI. 2002. Standar Pemeriksaan Kadar Timah Hitam Pada Spesimen Biomarker Manusia. Jakarta

Palar H. 2004. Pencemaran Tosikologi Logam Berat. Rineka Cipta. Jakarta.

Palar H. 2008. Pencemaran dan toksikologi logam berat - Cet. 4 PT. Rineka Cipta, Jakarta

Priyanto. 2010. Tosikologi,Mekanisme, terapi antidatum dan Penilaian resiko. Jawa Barat

Soedomo M. 2001. Pencemaran Udara, Penerbit ITB, Bandung. SPBU Bayaoge Kota Palu. Jurnal Biocelebes. Palu.

Suyono J. 1995. Deteksi Dini Penyakit Akibat Kerja, Buku Kedokteran.Jakarta : Depdikbud.

Sumardi. 2002. Validasi Metode Pengujian. Jakarta: Pusat Stardarisasi dan Akreditasi Sekretariat Jendral Depertemen Pertanian.

Widowati W. 2008. Efek Toksi Logam. Yogyakarta:Andi.Occupational Medicine

Wegscheider. 1996. Validation of Analytical Method, in Accreditation adn Quality Assurance in Analytical Chemistry. Berlin: Springer Verlag. 